IRSH 6I (2016), pp. I 97-222 doi:10.1017/S0020859016000237

(C) 2016 Internationaal Instituut voor Sociale Geschiedenis

\title{
Victory and Defeat: The Contentious Politics of One Generation of State Workers in China since the I960s
}

\author{
J U L I \\ Department of Sociology and Social Anthropology, \\ Central European University \\ Nador u. 9, I05 I Budapest, Hungary \\ E-mail: lijuo 26@gmail.com
}

\begin{abstract}
AвSTRACT: By analysing and comparing three waves of contentious collective action employed by the pioneering generation of Chinese state workers at one particular stateowned enterprise from the I960s to the present, this study aims to explain its varying forms and to analyse its effectiveness in different historical periods. I argue that the changing political opportunity structure in various historical contexts has greatly conditioned workers' "repertoire of contention" at each moment and, hence, significantly affected the processes, strategies, and outcomes of workers' contentious collective action. This article highlights the paradoxical role of the socialist social contract as a potential but crucial component of "the repertoire of contention", by arguing that different interpretations of the contract, as conditioned by a certain political opportunity structure in different historical periods, could either empower or disempower workers. Both archival and oral history research are used in this study.
\end{abstract}

This is the way the world ends Not with a bang but a whimper

T.S. Eliot, “The Hollow Men”

This article traces the history of contentious collective action conducted by one particular generation of workers in Chinese state-owned enterprises (SOEs). It describes a generation of workers who entered the factory during the Maoist period (I960s and I970s), worked through the socialist period, including the Cultural Revolution, into the early stage of economic reform in the 1980 s, and then retired before the radical SOE restructuring that began in the mid-I990s. ${ }^{I}$ Retiring prior to those radical reforms does not mean that

I. My greatest appreciation goes to these senior workers who warmly and trustfully shared their stories with me. I would like to thank Mahua sarkar and József Böröcz for their encouragement 
these workers escaped their turbulent and harmful social consequences: changes to pension and welfare provisions, two crucial components of the reform packages, had direct negative consequences for them. Moreover, most still saw their children and even grandchildren working in the same, now declining, factories. This, then, is a generation of workers who witnessed and experienced almost every stage of social change during the history of the People's Republic of China (PRC) from the I960s onwards. Along with adapting to these changes (passively or actively), they also engaged in various forms of contentious collective action, not only to make the changes less unbearable, but also to fight for their rights. At times, they succeeded; at other times, they failed. How, then, can we understand the various forms of contentious collective action chosen and adopted by this generation of workers and their consequent outcomes in different historical periods? By documenting and analysing instances of contentious collective action, this article aims to answer these questions.

Distinct from other recent labour studies that investigate the rising tide of labour insurgences among Chinese workers in the contemporary reform $\mathrm{era}^{2}$ this article provides a more systematic historical comparison by tracing and comparing three waves of contentious collective action as adopted by a particular generation of workers from the 1960 s to the present. To do so, I apply the "political opportunity structure" framework, developed by Sidney Tarrow and others, ${ }^{3}$ to investigate how the changing political opportunities and constraints these workers faced in different

while writing on this paper. I thank the editors and the anonymous reviewers of the International Review of Social History for their constructive comments.

2. See, for example, Yongshun Cai, "The Resistance of Chinese Laid-Off Workers in the Reform Period”, The China Quarterly, I70 (2002), pp. 327-344; Mary Elizabeth Gallagher, Contagious Capitalism: Globalization and the Politics of Labor in China (New Jersey, 2005); Ching Kwan Lee, "Pathways of Labor Activism", in Elizabeth J. Perry and Mark Selden (eds), Chinese Society: Change, Conflict and Resistance (London, 2000), pp. 57-79; Ching Kwan Lee, "From the Specter of Mao to the Spirit of the Law: Labor Insurgency in China", Theory and Society, 3 1:2 (2002), pp. I 89-228; Martin Hart-Landsberg and Paul Burkett, China and Socialism: Market Reforms and Class Struggle (New York, 2005); Feng Chen, "Privatization and its Discontents in Chinese Factories", The China Quarterly, I85 (2006), pp. 42-60; Ching Kwan Lee, Against the Law: Labor Protests in China's Rustbelt and Sunbelt (Berkeley, CA [etc.], 2007); Thomas B. Gold, William J. Hurst, Jaeyoun Won, and Li Qiang (eds), Laid-Off Workers in a Workers' State: Unemployment with Chinese Characteristics (New York, 2009); William Hurst, The Chinese Worker after Socialism (Cambridge [etc.], 2012).

3. Among many others, see Peter K. Eisinger, "The Conditions of Protest Behavior in American Cities”, American Political Science Review, 67:I (1973), pp. I I-28; Doug McAdam, Sidney Tarrow, and Charles Tilly, "Dynamics of Contention", Social Movement Studies, 2:I (2003), pp. 99-102; Charles Tilly and Sidney Tarrow, Contentious Politics (Oxford, 2006); Sidney Tarrow, Power in Movement: Social Movements and Contentious Politics (Cambridge, 20I I); David S. Meyer and Suzanne Staggenborg, "Movements, Countermovements, and the Structure of Political Opportunity", American Journal of Sociology, ıог:6 (1996), pp. I628-ı660; David S. Meyer and Debra C. Minkoff, “Conceptualizing Political Opportunity”, Social Forces, 82:4 (2004), pp. I457-1492. 
historical periods have affected the processes, strategies, and outcomes of workers' contentious collective action. Following Tarrow, the notion of "political opportunity structure" refers to "consistent - but not necessarily formal or permanent - dimensions of the political struggle that encourage people to engage in contentious politics". ${ }^{4}$ The key insight of this concept is, as David Meyer emphasizes, that contentious politics are always context-dependent. ${ }^{5}$ This means that contentious politics emerge and develop in response to changes in political opportunities and constraints, with participants employing their known "repertoires of contention". ${ }^{6}$

Within this framework, the paradoxical role of the socialist social contract is especially highlighted. The concept of a "socialist social contract", introduced by David Lane and others in the I 980 s before the downfall of eastern European real socialist societies, has been coined in particular to explain the relative acquiescence of industrial workers under socialist regimes. $^{7}$ It highlights the exchange relationship between the socialist state and its workers: the state provides tenured jobs and comprehensive welfare services; workers provide their compliance. While the general role of such a contract as at least ostensibly buying workers' acquiescence has become widely acknowledged, many scholars have challenged the idea of it being that dominant ${ }^{8}$ - rightly pointing out that, even under such a social contract, workers would not be totally bought out since they could still enjoy significant bargaining power, exemplified, for instance, by the widespread everyday resistance practiced by workers (such as foot-dragging,

4. Tarrow, Power in Movement, p. 32.

5. David S. Meyer, "Protest and Political Opportunities", Annual Review of Sociology, 30 (2004), pp. I $25-\mathrm{I} 45$.

6. Tarrow, Power in Movement, p. 2.

7. David Lane, Soviet Economy and Society (Oxford, I985); Peter Hauslohner, “Gorbachev's Social Contract”, Soviet Economy, 3:I (1987), pp. 54-89; Walter Connor, Socialism's Dilemmas: State and Society in the Soviet Bloc (New York, I988); Linda J. Cook, The Soviet Social Contract and Why it Failed: Welfare Policy and Workers' Politics from Brezhnev to Yeltsin (Cambridge, MA, I993).

8. See, for example, Charles F. Sabel and David Stark, "Planning, Politics, and Shop-Floor Power: Hidden Forms of Bargaining in Soviet-Imposed State-Socialist Societies”, Politics E Society, I I:4 (1982), pp. 439-475; Grzegorz Ekiert, "Rebellious Poles: Political Crises and Popular Protest under State Socialism, I945-89”, East European Politics E Societies, I I:2 (1997), pp. 299-338; Jason Sharman, Repression and Resistance in Communist Europe (London, 2004); Martin Hájek, Marie Dlouhá, and Tomáš Samec, "'Watch out for Politics': Exit, Voice and Other Strategies of Discontent in Late Czech Socialism”, Journal of Political Power, 7:3 (2014), pp. 393-4 I I; Jeffrey J. Rossman, Worker Resistance under Stalin: Class and Revolution on the Shop Floor (Cambridge, MA, 2009); Jeffrey Kopstein, “Chipping Away at the State: Workers' Resistance and the Demise of East Germany”, World Politics, 48:3 (1996), pp. 391-423. In the case of China, see, for example, Andrew G. Walder, "Wage Reform and the Web of Factory Interests”, The China Quarterly, Io9 (1987), pp. 22-4I; Feng Chen, "Subsistence Crises, Managerial Corruption and Labour Protests in China”, The China Journal (2000), pp. 41-63; Lee, "From the Specter of Mao". 
idling on the job, and stealing). This article contributes to these debates by enhancing the notion of the socialist social contract, arguing that the role of the socialist social contract is both context-dependent and often paradoxical in the different ways it was interpreted and legitimated by workers under changing political opportunity structures.

Generally, the concept of the socialist social contract consists of two parts: first, the regime provides secure employment, relatively egalitarian wage policies, and a full range of welfare services to state workers; second, workers give the regime their political compliance and acquiescence. While in previous studies these two parts seem to have been treated as equivalent units, I argue that two interpretations of the contract are possible, depending on the different priority and order placed on these two components. For instance, placing the priority on the first part of the contract would mean: "Unless the regime provides a fair and sound welfare framework as promised by socialist ideology, workers would not be acquiescent." Placing the priority on the second part, by contrast, would mean: "The regime would not provide these welfare services unless workers are acquiescent." Acknowledging these two possible interpretations of the socialist social contract is crucial, since it opens new insights for understanding not only the relationship between socialist states and their workers, but also (and particularly relevant in the context of the present article) the role played by the socialist social contract in workers' contentious politics. This novel approach reveals, as I will argue, that the socialist social contract does not simply "buy out" workers, and hence pre-empt their contentious collective action, nor does it merely offer unexpected spaces for everyday resistance, but rather it could also serve - when conditioned within a given political opportunity structure that allowed workers to interpret the socialist social contract in the first rather than the second wayas a crucial component of the "repertoire of contention" for workers in organizing effective collective protests and bargaining. Under such circumstances, the existence of the socialist social contract would empower rather than disempower them.

As I will show in this article, both the radical political environment of the Cultural Revolution and the subsequent development of a more lenient and paternalistic socialist factory regime during the earliest stage of reform in the 1980 opened new possibilities for workers to access political spaces and to confidently organize contentious collective action by highlighting and defending the first part of the socialist social contract - the promise of a sound and fair socialist welfare framework as propogated by official ideology - while implying the acquiescence of the workers under the second part to be conditional. Conversely, when the political opportunity structure changed and workers' political access disappeared, the socialist social contract became interpreted in the second way and, hence, could efficiently "buy out” workers' acquiescence. 
Moreover, when the socialist social contract was unilaterally broken by the state from the mid-I990s onwards, and when the rhetoric of a "workers' state" became increasingly outdated, workers who still desperately or doggedly stuck to the old idea of a socialist social contract as the fundament of their "repertoire of contention" had to realize that it had lost its original legitimacy and force and was becoming less and less effective. Subsequently, turning to the law - the supposed foundation for a new social contract ${ }^{9}$ - as an alternative ground for their contentious politics proved, for them, more like a final blow than a rescue. The formal interpretation of the law, strongly biased in favour of the big corporations, along with the opaquely bureaucratic procedures of the legal process, not only gave rise to a strong sense of exclusion among these senior workers, but also greatly contributed to their final defeat.

The case factory here is a state-owned steel factory located in Sichuan province, usually called Changcheng Special Steel (CSS) ${ }^{10}$ Established in 1965 as part of the Third Front Construction (TFC, San Xian Jian She), one of the largest socialist industrialization projects and a bulwark against the threat of war from both the United States and the Soviet Union, ${ }^{\text {II }}$ the factory proceeded through some hard and unstable early years, experienced dynamic development and even prosperity during the first stage of reform in the I980s, then, after initially faring well, went into decline during the turbulent radical reconstruction that began in the mid-I990s; currently, CSS is lingering on the edge of bankruptcy. Throughout these different periods, the workers featured in this article employed various kinds of contentious collective action, which are analysed in the following sections.

This article is based on oral history and archival research (the latter including perusal of the accessible parts of the internal factory archive of CSS). The oral testimonies of workers (fifty-three in total) were collected during a series of intermittent research stays at CSS and in the surrounding community between 2007 and 2013. All of the workers I interviewed were

9. For this process see, for instance, Lee, Against the Law; Wenfang Tang and William L. Parish, Chinese Urban Life under Reform: The Changing Social Contract (Cambridge, 2000).

Io. The factory was called Changcheng Special Steel (Changcheng Teshu Gang Chang) until it was merged with Pangzhihua Steel in 2003. Now, it is called Panggang Group Changcheng Special Steel.

I I. For a detailed history of the Third Front Construction, see Donglin Chen, Sanxian Jianshe: Beizhan Shiqi de Xibu Kaifa [The Third Front Construction: A Western Developmental Project in War-Preparing Periods] (Beijing, 2003); Ju Li, “All that is Solid Melts into Air? An Exploration of the Transformation Process of a Third-Front Enterprise in China" (Ph.D., Binghamton University, 2012), pp. 22-45. See also Donglin Chen, “Cong 'Chichuanyong Jihua' dao 'Zhanbei Jihua' - 'Sanwu' Jihua Zhidao Sixiang de Zhuanbian Guocheng” [From "The Plan of Food, Clothing and Daily Necessities" to "Preparing the War" - The Changing Process of the ThirdFifth Thoughts], Dangdai Zhongguo Shi Yanjiu [Contemporary Chinese Historical Research], 2 (1997), pp. 65-75. 
in their seventies or eighties in this period and had been retired since the I980s or early i990s. Most of them lived on their pensions, which were barely enough for subsistence, and a few received extra financial help from their adult children. All the interviews were recorded with the interviewees' permission and later transcribed.

\section{“RIDING ON THE TIDE": CONTENTIOUS POLITICS DURING THE CULTURAL REVOLUTION}

Most workers I focus on in this article are CSS's so-called pioneering workers, who were transferred to this plant from various "mother factories" in the mid-I960s and early I970s. Given the TFC's defensive intent, almost all Third Front projects had to be located in the most remote areas of inner China, described in the official guideline as "near the mountains, easy to hide, and geographically decentralized" (Kaoshan, Yinbi, Fensan). ${ }^{12}$ Most of these enterprises were built from nothing. Confronted with a shortage of technology, equipment, and experienced labour at the locations of most Third Front enterprises, the central state had to mobilize and, when necessary, enforce massive migration using a strategy named "three ways for veterans to help beginners". This required that: old industrial locations should help new industrial bases; that old enterprises should help new enterprises; and that senior workers should help junior ones. By utilizing this strategy, the state created a continuous flow of managers, workers, equipment, and technologies from the "mother" enterprises to newly built Third Front enterprises. ${ }^{\text {I3 }}$

While some people volunteered to migrate for various reasons, including their sincere beliefs in patriotism and socialism, others were simply assigned to new locations, sometimes against their will. ${ }^{4}$ The first group of workers arrived at CSS in 1965 , as the so-called preparatory team. ${ }^{\mathrm{IS}}$ Under the slogans of "first production, then living" and "hard work, plain living", these workers had to build their own mud cottages for accommodation upon arrival. Both historical archives and oral histories show that early life

I 2. Jian Ren and Chen Mo, "Sanxian Jianshe de Huihu yu Fansi" [Reflections on the Third Front Construction], Junshi Lishi [Militancy History], I:28 (200I), pp. 27-3 I, 28. All translations from Chinese are mine.

I 3. For more information, see Chen, "Cong 'Chichuanyong Jihua' dao 'Zhanbei Jihua”, pp. 65 -75. I4. Ju Li, "How It Was/Is Told, Recorded and Remembered: The Discontinued History of the Third Front Construction", Journal of Historical Sociology, 28:3 (20I5), pp. 3I4-34I, $325-328$.

I5. Changcheng Gangchang Danganshi [Changcheng Steel Factory Archival Office], Jiangyou [hereafter, CSS Archive], Changshi Xiezuo Weiyuanhui [The Writing Committee of Factory History], "Changcheng Teshu Gangchang Changshi: 1965-1985" [The History of Changcheng Special Steel Factory: 1965-1985], 1986, p. 32. 
at CSS was extremely harsh and arduous. ${ }^{16}$ Complaints were rampant: several urgent meetings were called in order to deal with workers' resentment and low morale. ${ }^{17}$ Despite this, however, there is no record of collective protests during this earliest period at CSS. Collective bargaining and protests were a feature of other TFC projects, but even then they seemed sporadic and ephemeral. ${ }^{18}$ As rightly observed by the historian Jackie Sheehan, during the first half of the I960s, "the policy of combining suppression, persuasion and limited concessions restored order in enterprises", and hence "stifled workers' protests" in general. ${ }^{19}$ By implying that the regime would not provide secure jobs without workers' compliance, the socialist contract seems largely to have pre-empted workers' potential for contentious collective action.

In opening up political spaces for ordinary workers in a quite radical way, the coming of the Cultural Revolution in I966 swept away such general acquiescence. Following Mao Zedong's slogans such as "to rebel is justified", "smashing up the old world and building up a new one", or "against the bureaucracy", previously latent or suppressed conflicts, anger, and resentment were suddenly released and burst out in numerous rebellious movements with various aims and interests. Holding tightly to the rhetoric of the "working class leading everything" as the crucial essence of socialist ideology, large sections of workers launched immense mobilizations in often highly organized ways and demanded the fulfilment of the rights promised by the socialist social contract, including "equal pay for equal work", "workers' self-management", and "workers as the real master". ${ }^{20}$

16. Li, "How It Was/Is Told”, pp. 322-323, 329-33 I.

17. CSS Archive, "Guanyu Zuohao Dan, Shuang Zhigong he Jiashu Sushe Anzhi Gongzuo de Jueding" [The Issue about Helping Newcomers to Settle Down], i 2 March 1965.

I 8. An example of such collective action in this early period is a protest staged in August I965 by 250 workers, originally from the Kailuan coal mine but later relocated to the Yunnan Yangchang coal mine (one of the Third Front enterprises), demanding higher food quotas, increased mining allowances, healthcare expenses, and higher wages. After the protest, i 50 workers walked to the nearby county bus station and demanded a bus to the city of Ansun; from there, they planned to take the train back to Kailuan, their "mother factory". When their requests were refused and their departure was blocked by the government, they surrounded the municipal offices until at least some of their demands were met. Similar events elsewhere must have drawn official attention to the threat of such resistance. Before the National Day in 1965 , for instance, the National Construction Committee, the Ministry of Metallurgical Industry, and the Metallurgical Office in Sichuan issued several documents successively, demanding that local governments ensure no petitions should be submitted or demonstrations held by relocated workers in Beijing or Chengdu (the provincial capital) during the holidays. See CSS Archive, "Guojia Jibeng Jianshe Weiyuanhui Guanyu Zuijin Fasheng de Jiqi Neiqian Zhigong Nongshi de Qingkuang Tongbao" [Notification from the State Infrastructure Commission about the Several Recent Affrays Among Relocated Workers], i7 September 1965.

19. Jackie Sheehan, Chinese Workers: A New History (London, 2002), p. 85.

20. For workers' mobilizations during the Cultural Revolution see, for instance, Elizabeth J. Perry and Li Xun, Proletarian Power: Shanghai in the Cultural Revolution (Boulder, CO, 1997); Sheehan, Chinese Workers, pp. 103-1 38. 
Besides these organized and large-scale labour mobilizations, workers also simply deployed the language of the Cultural Revolution and "rebelled" in more spontaneous ways at the grass-roots level. At CSS, resentment about the numerous forced relocations finally came to boiling point. Emboldened by the rhetoric of anti-bureaucracy and mass rebellion, resentful workers now demanded, in a quite violent way, their return to their "mother factories". Gongyi, daughter of the general party secretary at CSS at that time, describes in detail what happened to her father during the Cultural Revolution:

Every evening at 7.00 p.m., the loud horn in the factory would repeatedly announce the place and time of the tribunal meeting against my father. Posters were everywhere with my father's name on it, denouncing him as the enemy of the proletarians. These rebellious workers forced my father to sign the permits needed for them to return to their mother factories [...]. They beat him [...]. My father almost died [...]. If my father had not been chosen by the party as one of the leaders to establish this factory, he wouldn't have been attacked that much during the Cultural Revolution. ${ }^{21}$

This narration points not only to a dark and violent dimension of workers' contentious politics during this period, but also to a commonly held belief among these workers: "I will not comply unless the provision is fair and acceptable". This interpretation of the socialist social contract, made possible by the ambitious and maximalist socialist rhetoric during the Cultural Revolution and its anti-bureaucratic thrust, thus provided a strong legitimacy for violent collective action by workers. Nevertheless, dilemmas lurked behind these events. While the particular political opportunity of the moment did grant workers a certain level of confidence and power against the low-level cadres within their reach, their structural dependence upon the regime for the tenure of their jobs - also a crucial element of the socialist social contract - delimited their power: they still needed a permit from the attacked cadre to be able to leave. Hence, as an individual bureaucrat, this cadre could be overthrown and beaten, but, as the representative of the regime, he still held considerable power, even when boldly challenged by rebellious workers, sometimes successfully: quite a number of workers finally gained a permit and returned to their mother factories.

The Cultural Revolution ended in 1969; meanwhile, escalating tensions between China and the USSR ignited by the Zhenbao Island (Damansky Island) incident in March 1969 made the threat of war seem even more imminent than before. In this way, the Third Front Construction project once again became a prominent and urgent task in China's general policy

21. As mentioned, all interviews were conducted between 2007 and 2013, at CSS, Jiangyou. Interviewees were granted non-disclosure of their full names. Interview, Gongyi, 8 October 2008. 
orientation. $^{22}$ To this end, the central government soon established a committee to oversee the recovery of the Third Front project, which had emerged badly harmed from the Cultural Revolution, while at the same time setting up so-called Military Control Commissions (MCC, Jun Guan Hui) at every Third Front site. ${ }^{23}$ At CSS, the newly established MCC immediately suppressed any rebellious behaviour, restored order, and resumed work on further expanding the factory. ${ }^{24}$ The political spaces once opened up by the Proletarian Cultural Revolution had now been closed. When, in I97I-I973, many more workers were transferred from various mother factories to CSS, no open, individual, or collective disturbance was heard or recorded. ${ }^{25}$ It seemed that the socialist social contract had again resumed its "normal" role: the regime would not provide tenured jobs and other welfare services unless workers were compliant.

Nevertheless, while order was restored, changes did take place in response to the preceding movements. For example, after the MCC left the factory in 1973 it was the leaders of the Cultural Revolution mobilizations who came to form the main body of the new CSS leadership. ${ }^{26}$ This seems to confirm some scholars' observations that there was a degree of increase in workers' participation in management in state-owned factories after the Cultural Revolution. ${ }^{27}$ More importantly, as I will discuss in some detail below, workers' experiences during the Cultural Revolution (whether at CSS or in other factories) seemed to have bequeathed them a new pride in their proletarian status, along with the use of a powerful language of class and a strong confidence and readiness to fight against managers and unwelcome policies. ${ }^{28}$ Meanwhile, the memory of the rhetoric of "to rebel is justified" and the real experiences of confronting the low-level cadres also led to a persistent questioning of

22. Jun Niu, "I 969 nian Zhongsu Bianjing Congtu yu Zhongguo Waijiao Zhanlie de Tiaozheng” [The Border Conflicts Between China and the USSR in 1969 and the Revision of China's Foreign Policies], Dangdai Zhongguo Shi Yanjiu [Contemporary Chinese Historical Research], 3 (I996), pp. 66-77.

23. Chen, Sanxian Jianshe, pp. 199-208.

24. CSS Archive, "Changcheng Teshu Gangchang Changshi”, p. 5 I.

25. This statement is based on the oral accounts of both senior cadres and workers at CSS, since no factory archives are accessible for the period I967-1977.

26. CSS Archive, "Changcheng Teshu Gangchang Changshi”, p. 67.

27. See, for instance, Sheehan, Chinese Workers, pp. I 39-1 55; Stephen Andors, "Two Documents on Workers' Participation in Management on the Shanghai Harbor Docks in the I970s", in idem (ed.), Workers \& Workplaces in Revolutionary China (New York, 1970), pp. 38 I-402; Andrew Walder, "The Chinese Cultural Revolution in the Factories: Party-State Structures and Patterns of Conflict", in Elizabeth Perry (ed.), Putting Class in its Place: Worker Identities in East Asia (Berkeley, 1996), pp. 167-198.

28. Other scholars have made similar observations. See, for example, Perry and Xun, Proletarian Power, p. 193. 
managerial legitimacy among these pioneering workers, long after the Cultural Revolution. ${ }^{29}$ All of these, together with the continuing centrality of the socialist social contract, constituted important components of the "repertoire of contention" for later contentious collective action by workers.

\section{"WE ARE STILL THE BIGGEST BROTHER": WORKERS' CONTENTIOUS POLITICS \\ IN THE EARLY STAGE OF REFORM}

From the end of the I970s, groundbreaking economic reform started in China. Despite its later development, the earliest stage of reform during the I 980 s was - as rightly observed by Wang Hui - more like an effort of self-reflection and self-correction by the Chinese socialist regime to resume, in a more "rational" way, the socialist modernization project that had been interrupted by previous radical political movements than a deliberate embracing of any kind of capitalism. ${ }^{30}$ Compared to the agricultural reforms initiated several years earlier, at this early stage, the SOE reform was even more cautious and had clear political limitations following a "cage and bird" theory, which insisted that SOEs were a bird with its wings untied, but that it could fly only within the "big cage" of a socialist state-owned economy. ${ }^{3 \mathrm{I}}$

Hence, two trends can be observed for this period, at CSS as well as in other SOEs. First, decentralization and profit retention, as two major aims of early SOE reform, provided more money and autonomy to the factory for developing a more prosperous industrial community while also raising the living standards of ordinary workers. Meanwhile, a consumer market outside the factory supply network slowly emerged, due largely to earlier agricultural reforms; cautious growth of non-state economic sectors outside the planned economy began to offer state workers some alternative employment opportunities, though they were still perceived as suboptimal choices at that time. By weakening workers' structural dependence upon the regime, all these developments helped to create a different labour regime at CSS that can be labelled "bureaucratic paternalist". ${ }^{32}$ Second, by the second half of the I980s the central government had begun to endorse a series of reforms that sought to give factory managers more authority, as

29. Martin Lockett, "Enterprise Management: Moves towards Democracy?", in Stephan Feuchtwang and Athar Hussain (eds), The Chinese Economic Reforms (New York, 1983), pp. 224-256, 230.

30. Wang Hui, "Contemporary Chinese Thought and the Question of Modernity", Social Text, 55 (1998), pp. 9-44, I 5-I6.

3 I. Xiaobo Wu, Jidang Sanshinian [The Turbulent Thirty Years] (Beijing, 2008), p. 67.

32. Li, All that is Solid, pp. I I2-I45. 
well as to introduce more flexible labour policies. ${ }^{33}$ Power thus came to be concentrated increasingly in the hands of factory managers, and income gaps (in wages, bonuses, and the assignment of housing) between workers, but especially between workers and managers, widened markedly. ${ }^{34}$

These two contradictory trends generated a sort of tension within the socialist social contract that saw the simultaneous betterment of welfare provisions and the beginnings of different kinds of status degradation and threats to job security. However, since the political "cage" in this period was still in place, the socialist social contract between state and state workers, while becoming more shaky, remained largely preserved: the tenure labour system remained intact; management still did not develop any enhanced powers against workers, such as the threat of lay-offs; and the cautious efforts by the government in the I 980 s to introduce a more flexible labour system remained largely ineffective. Thus, when, in I988, the state started to encourage enterprises to cut down on "redundant" workers in order to deal with widespread "overmanning", in practice they fired virtually no workers, although some were put on reduced wages. ${ }^{35}$ Following this general situation, the contract labour system introduced at CSS in I986 applied only to newly recruited employees, while the status of existing permanent workers did not change at all.

Nevertheless, these two trends provided a particular political opportunity structure for workers of the pioneering generation, many of whom retired during this period. While the second trend of granting managers more power and privilege over workers effectively provoked their protests, the first trend of a hegemonic and paternalistic factory regime with better welfare provisions supplied resources and opportunities, particularly to this group of workers. Thus, armed with an early acquired set of militant experiences, memories, and language, reassured by the persistent socialist ideology and social contract, encouraged by rising living standards and the development of a paternalistic and hegemonic factory regime, and protected by their newly attained pensioners' status, which was at least immune to the threat of job loss, these workers relaunched their protests. Once more, the political opportunity structure legitimated their collective action by re-employing the interpretation of the socialist social contract in the same way as during the Cultural Revolution: "We will not comply unless provisions are fairly distributed as promised by socialist ideology."

33. Wing-yue Leung, Smashing the Iron Rice Pot: Workers and Unions in China's Market Socialism (Hong Kong, 1988), p. 99.

34. Sheehan, Chinese Workers, pp. 197-198; Anita Chan, "Revolution or Corporatism? Workers and Trade Unions in Post-Mao China", The Australian Journal of Chinese Affairs, 29 (1993), pp. 3I-6I, 40; Andrew Walder, "Workers, Managers and the State: The Reform Era and the Political Crisis of 1989”, The China Quarterly, I 27 (1991), pp. 467-492, 479.

35. Barry Naughton, Growing Out of the Plan: Chinese Economic Reform, 1978-1993 (Cambridge, I996), pp. 2 I I-2I 8. 
Cuiye is a retired worker and activist in his eighties who arrived at CSS in I97I after being transferred from another factory. He was always called "old revolutionary" by other workers because of his unflinching adherence to socialist ideals and his steadfast readiness to put up a fight against the cadres. Bold, but also shrewd, he was one of the core figures among the defiant pensioners and played a crucial role in almost every collective action of the time. In interview, he tells one particularly vivid and bold story about a victorious struggle he and his comrade-pensioners had fought against the cadres at CSS during the I980s:

That was in 1983 or 1984 . I had already retired. I was not convinced by some behaviours of the cadres [...]. Their only concerns then were production; they didn't care for workers' welfare, and they did not implement the mass $\operatorname{lin}^{3^{36}}[\ldots]$. So I posted small posters everywhere. These small posters were copies of a government document about anti-corruption. ${ }^{37}$

Unlike the official historiography, which identifies the threshold of the "new era" as either 1976, when the Cultural Revolution is said to have officially ended, or 1978, when the process of economic reform was initiated, many pensioners like Cuiye would refer to the years $1982-1983$ as the real turning point in CSS's history. This view is corroborated not only by factory documents and reports from the time, but also by the official factory newspaper, Changgang Bao [CSS News]. ${ }^{38}$ It was precisely from 1982 onwards that issues such as fulfilling production quotas, increasing enterprise autonomy, strengthening labour discipline, wage rises, and bonus distribution replaced the earlier topics, which revolved around politics and class struggle. Moreover, it was during 1983 that the management of CSS was restructured following the government's call for a "younger and more educated leadership" in SOEs. For the first time in CSS's history, "intellectuals" (i.e. persons with college degrees), rather than senior workers, formed the main body of its management. That some crucial changes began to occur around this period was keenly perceived by workers like Cuiye. Cuiye's complaint about cadres caring more for production than workers' welfare and hence not implementing the "mass line" may be understood against this background. In protest, he posted denunciatory posters and soon got himself into trouble: he was caught while posting them and taken to the security department.

36. The mass line (qunzhong luxian) is the political, organizational, and leadership "method" developed by Mao Zedong and the Chinese Communist Party during the Chinese Revolution. The essential element of the mass line is consulting the masses, interpreting their suggestions within the framework of Marxist-Leninism, and then enforcing the resulting policies.

37. Interview, Cuiye, 25 July 2010.

38. Changgang Bao is the internal daily newspaper, published by the factory since 1977 , though after 2002 its publication became somewhat more irregular due to turbulent restructuring. Many large-scale state-owned enterprises in China published their own internal newspapers, under the auspices of the propaganda department of the enterprises. 
Still, in the interviews, he prides himself on having remained staunch and undaunted:

The department chief there asked me why I had put up small posters. I replied to him that it was my freedom and right to do so. The chief said that what I was doing was destroying the production. I told him that was shit. Then, after only five minutes, all the other retired workers heard about this incident. They soon gathered and surrounded the security department building. When the chief saw so many people, he became afraid. He begged me to go home. He said, "We did something wrong, so we apologize to you. Please go home." I said, "Arresting people without reason is illegal. So now you have to tell me what illegal things I did. Or is putting up small posters for anti-corruption illegal? Is that your logic?" I did not leave. I stayed in their office, and all the retired workers stayed outside to support me. I was afraid of nothing [laugh]. I stayed there for three days. They had to bring me good food during the daytime, set up a bed for me during the night and take turns serving me [langh]. The retired workers took their daytime and night-time shifts, too, always staying outside to support me [...]. I know how to deal with these bureaucrats. I am not afraid of them at all. There were so many people behind me. ${ }^{39}$

"There were so many people behind me" - that was the greatest strength behind Cuiye's "fearless" and cunning behaviour. It was also the reason the cadres were so ready to cave in. Such collective solidarity within this generation of workers came from their shared working and living experiences as well as from the communal public spaces they occupied. Most had come to CSS during the earliest period of Third Front Construction and had spent their lives together in this factory community. Before retirement, they had worked together; after retirement, they went to the same farmers' market, exercised in the same parks, and played cards or Majiang in the same teahouses. My interviews show that, while never forming any organization in terms of an administrative or functional structure, these pensioners could nevertheless behave in quite effective and prompt ways: they distributed information in the farmers' market, teahouses, and parks; sometimes, when there were some important matters, notices would be posted on the public notice boards in different residential areas, calling for a meeting; at other times, urgent issues would be communicated by phone. In this way, information could be distributed rapidly and, most of the time, pensioners responded promptly. This is exactly what happened according to Cuiye's proud account, when he claims that within five minutes of his arrest his loyal comrades appeared, to back him up. These forms of resistance, which, following James Scott, emerge from "dense informal social networks and rich, historically deep, subcultures of resistance to outside claims", ${ }^{\circ}$ were also observed by other scholars working on Chinese SOEs, especially for the I980s, when their

39. Interview, Cuiye, 25 July 2010.

40. James Scott, "Everyday Forms of Resistance”, Copenhagen Journal of Asian Studies, 4 (1989), pp. 33-62, 52 . 
industrial communities were steadily growing. Numerous studies have pointed to the strong bargaining power vis-à-vis management that workers obtained from such dense informal social ties. ${ }^{4 \mathrm{I}}$

Another victorious act of resistance organized by the pensioners during this period, as repeatedly recounted to me during the interviews, involved a protest against the assignment of housing in 1986. In that year, CSS built two residential apartment buildings that offered larger flats than normal ones. According to the initial plan, these larger flats would be assigned to cadres. However, when the pensioners heard this news, they immediately gathered and surrounded the administration building. Cuiye recounts the event:

We had about 700 pensioners surrounding the administration building. The enterprise said that these flats were for cadres. We asked why? There were still so many workers who didn't have decent places to live. Why the cadres? What kind of contributions did the cadres make? Who contributed more to the enterprise and the country: workers or cadres? Without workers, your cadres were just shit! We told them that the working class was still the greatest; the working class was still the "Big Brother"; ${ }^{2}$ and your dangguande [cadres] were as small as ants. We told them that if they dared to give these flats to cadres, we would smash their offices. I said that at that time. I said you could try to see who were more fearless, you or us. They became scared. Later, the factory decided to assign all these flats to the pensioners, as we asked in the beginning. We told them that these flats had to be given to the pensioners because they were becoming old and they should enjoy their old age, according to our socialist country's policies. ${ }^{43}$

In the second half of the I980s, when the reform agenda became both more consolidated and more outspoken, "intellectual cadres" (i.e. those who had university degrees) now unquestionably consolidated their power against workers not only in the production process, but also within the spheres of distribution. In both legal and illegal ways, more and more benefits went into managers' pockets. Managerial privileges that had been temporarily suppressed by harsh political movements in the past quickly re-emerged (together with what previously had been targeted as corruption). In a 1986 survey of 640,000 workers in 519 Chinese enterprises, conducted by the Federation of Labour Unions, more than half of workers believed that their status had declined since reform. They complained: first, that their political status had declined, since recruitment for party membership now favoured

4I. See, for instance, Yanjie Bian, "Bringing Strong Ties Back In: Indirect Ties, Network Bridges, and Job Searches in China", American Sociological Review, 62:3 (1997), pp. 366-385; Tang and Parish, Chinese Urban Life under Reform, pp. I 3 I-I 32.

42. "Working class as the Big Brother" was a popular saying during the period of planned economy in China. After the Chinese Revolution, workers were hailed as the leading class in China, hence the "Big Brother".

43. Interview, Cuiye, 26 July 2010. 
"intellectuals", not workers; second, that income and welfare policies no longer favoured workers, but intellectuals, cadres, veterans, and peasants; third, that disciplinary measures against workers had become too harsh, whereas the supposed "servants" under the socialist regime - managers and bureaucrats - were now penalizing the "masters" - workers; and fourth, that workers now had no say in enterprise decision-making, with "democracy at the workplace" only an empty slogan. ${ }^{44}$ Such discontent was widespread, but might have been felt more intensely among pensioners, who still harboured a fresh (and often positive) memory of the revolutionary past, along with a strong scepticism towards managerial authority and legitimacy.

Meanwhile, slogans like "the working class is the Biggest Brother" were not yet being openly challenged, not even by the managers, and the pride of being a "socialist worker" was still cherished by this generation of workers. The image of the working class as brave and fearless, which had been cultivated by the socialist state and strengthened during the rebellious era of the Cultural Revolution, persisted among these pensioners. ${ }^{45}$ In addition, they had little to lose: they had already retired, so the promise or threat of gaining or losing a tenured job no longer concerned them, and their pensions were guaranteed, so that it seemed no real harm could be inflicted on them. Therefore, they could confidently claim that it was still the working class, not the managers, who created the country's wealth; they could legitimate their protests by still interpreting the socialist contract as: "Unless the social provision is fair and conforms to socialist ideology, we will not comply." Once again, they won a victory and management yielded to their demands.

What part did the workers employed at CSS at that time play in these protests? Significantly, my research finds that no collective protest ever took place among the younger workers of this period, although different kinds of less open "everyday resistance" might have widely occurred. This difference needs to be understood through the lens of the different "repertoires of contention" that these two generations of workers had at their disposal. The two trends pointed out above - a paternalistic factory regime accompanied by improving living standards and an emerging flexible labour management system - had a quite effective role as "carrot and stick" upon those employed and seemed to have successfully, if only ostensibly, bought their loyalty; so much so that many then-employed workers actually regard this decade as the "golden age" of the factory. Similarly, they might also recoil more at potential penalties, like wage/bonus deductions or even dismissal under the more flexible 
labour policies (used particularly against those getting involved in labour activism).

Another reason for the younger generation's absence from these protests would be their already more strained and ambivalent attitude towards the tenets of socialist ideology and a lack of the kind of rebellious experiences that the pensioners had lived through. The older generation had spent most of their working lives in the Maoist era and thus had the most vivid memories of the more "mobilized" socialist past as a lived historical alternative to Chinese society of the late I980s, especially the Cultural Revolution at the end of the I960s. The younger generation, who entered the factory during the I970s and I980s, when the political environment stopped encouraging radicalism and militancy, did not share that experience. Under these constraints, the socialist social contract was more likely to be interpreted as: "The state/factory can take away your tenured job and the accompanying welfare unless you are compliant."

This was not the case for the pensioners, whose experiences gave them more confidence and resources to fight for their interests based on their interpretation of the socialist social contract. In part due to the clearly defined limitations of this early stage of reform (the "cage" for the bird), which supported the persistence of the socialist social contract, managers were always likely to cave in, and pensioners were in a good position to win. Such victories did not last long however. After the mid-I990s, when the reform agenda became less and less bound by the political restraints of the "cage", eventually leading to the outright abandonment of the socialist social contract - the most crucial component of pensioners' "repertoire of contention" - these pensioners were never to win again.

\section{ULTIMATELY DEFEATED: PENSIONERS' CONTENTIOUS COLLECTIVE ACTION AFTER THE RADICAL MARKET REFORM}

At the Fourteenth National Congress of the Communist Party of China (CPC) in October 1992, President Jiang Zemin delivered a comprehensive and consequential report that highlighted the substantial achievements of economic reform and outlined the major tasks in economic and social development for the coming decade. In this report, for the first time, the central state clearly declared that the goal of China's economic reform would be to establish a socialist market economy. Though the adjective "socialist" remained, in hindsight it appeared more a nominal concession to conservative sectors than a real pledge; the core term now was "market economy". This significant statement finally unfettered the ongoing reform from socialist ideological constraints and paved the way for a more radical market agenda. Soon afterwards, from the mid-I990s, closures, 
privatizations, mergers, large-scale lay-offs, reductions in welfare provision in the name of cost-cutting, and forceful early retirements were all imposed on the SOEs by the different arms of governments. Eventually, the previous socialist social contract between the state and state workers was unilaterally suspended, ${ }^{46}$ numerous SOEs bankrupted, and the labour regimes in most surviving SOEs became increasingly harsh. ${ }^{47}$ CSS was no exception: huge lay-offs occurred in 1997 when about half of its workers were let go, while the remaining workers were quickly pauperized due to lower wages and cuts in welfare provision. The community disintegrated, and the threat of bankruptcy constantly haunted everyone. ${ }^{48}$

For the pioneering generation of workers, these transformations happened so dramatically and swiftly that the first reaction was bewilderment rather than resistance. The radical restructuring agenda dragged most of them and their families into semi- or outright poverty, particularly as their retirement pensions had increased only very slowly over the previous years and remained extremely low relative to rising living costs. Worse, most of their children and even grandchildren still worked in the factory and were constantly confronted with the threat of lay-offs, an increasingly hazardous working environment, and low wages. Resentments accumulated as time passed. Then, in 2002, when the enterprise decided to stop subsidizing pension payments, the already tense situation exploded.

The root of this confrontation lay in the incomplete and erratic pension reform that had occurred. As part of the state's efforts to restructure SOEs into "modern enterprises", pension reform had been implemented at CSS from the mid-I990s. Under this new pension system, the social pension fund would be built by pooling together contributions from the local government, the enterprise, and the individual worker, rather than from the enterprise alone as previously. In addition, the funds from the enterprise were, by default, not to exceed twenty per cent of its total payroll costs. Prior to the reform, however, CSS, like many other SOEs, not only paid retirees their pensions, but also offered them several kinds of enterprise subsidies as part of its welfare programme. With the change, local governments refused to share the expenses with the factory. So, even after the pension reform, in addition to paying their "official" portion of pension funds the enterprise still had to raise these subsidies on its own. Enterprise management had long regarded this as a large and unfair burden. In January 2002, when the central government issued a new

46. Also see ch. 6 on "Labor-Management Relations" in Tang and Parish, Chinese Urban Life under Reform.

47. Some authors use the notion of "despotism" for this new labour regime. See, for instance, Ching Kwan Lee, "From Organized Dependence to Disorganized Despotism: Changing Labour Regimes in Chinese Factories", The China Quarterly, I 57 (1999), pp. 44-7I.

48. For a detailed analysis of the situation at CSS and the surrounding community in the I990s, see Li, All that is Solid, pp. 179-19I. 
policy to increase pensions for SOE pensioners by a rather small amount, ${ }^{49}$ CSS decided to use this occasion to reduce its subsidies in proportion to the increase in the pension payment. In this way, if one retiree received a fiftyyuan increase in their pension under the state policy, then the enterprise would deduct fifty yuan from his/her enterprise subsidies. Although this was not a major issue at first sight, since the nominal amount in question was quite small, it nonetheless served as a final straw and triggered the largest, longest, and most militant and desperate protest in CSS's history.

The same day that the pensioners were officially informed about the decision, they immediately set up an organizing committee formed from their elected representatives. The next day, several thousand retirees besieged the factory's administration building. After getting no immediate response from the administration, angry retirees broke into and partially occupied the building, a kind of action inherited from the Cultural Revolution. Always led in a highly organized fashion by the committee mentioned above, the siege and occupation lasted almost six months. As time passed, the atmosphere grew tenser; the protest swelled in size and became more violent. Laoyin, the official union chairwoman at the time, recounts the first days after occupation in great detail:

After the document was dispatched, I dared not go to my office for two days. These retired workers were everywhere in the building. Then, on the third day, the enterprise asked me to talk to these workers since I was the labour union chairwoman at that time. From that day on, I spent five months standing in the hall of the administration building, trying to calm down these angry workers by talking through a loudhailer. There were so many people in the building, these old people. They sat or stood everywhere, with their hair as white as snow. They demanded that I go outside and talk to more workers. They said that the hall was too small. I dared not. But they insisted. Once, two old gentlemen forcibly grabbed my arms and another old lady underneath tried to pull me down the stairs. Fortunately, there were several plainclothes policemen around me and they seized me back from these angry old people. Our policy at that time was to swallow all the beating and scolding, and never to provoke further escalation or to fight back. A lot of these old workers used to be so nice and they also knew me very well - I had always called them "aunt" or "uncle". But now they hated me, they hated me so much that I thought they might kill me. ${ }^{50}$

All the grievances and anger that had accumulated through the years of radical reform, along with the sense of having been betrayed and abandoned, had finally erupted. In interviews, numerous retirees told me that what they had done was not for the small amount of money but for their dignity and "backbone". "We can't swallow the resentment anymore; we can't let them do

49. The nominal increase ranged from forty-five to sixty yuan per month, while the average monthly pension was about $\mathrm{I}, 000$ yuan.

50. Interview, Laoyin, 3 August 20 I r. 
whatever they want", the tenor would be. The confrontation went on until, in May 2002, the enterprise's administration finally convened an urgent meeting in the factory's grand auditorium. The meeting was intended to facilitate a dialogue between the protesters and the most senior management of the enterprise. However, it ended in chaos and violence. Laoyin describes the event:

That day was a nightmare for me. We were in the auditorium. The police cars stayed outside in case we needed to escape [...]. Before the meeting even had a chance to start, these old people simply pushed forward and rushed up to the stage. We all thought they were going to beat us. We were so frightened that we ran away immediately. Several managers took a shortcut corridor behind the auditorium. I ran to the police car outside the auditorium. When the workers found out that all other managers had already run away except me in the police car, they were so angry that they surrounded the car and even lifted it up. I sat inside, shaking, watching the never-ending flow of people rushing forward, their waving fists, and their fingers pointing to my nose from behind the closed car window and cursing me [...]. I would never blame these pensioners. Everybody needs to survive. I just hoped that I could do more for them, but I didn't have such power. What kind of cadres were we in these loss-making SOEs!

Interestingly, workers' indignation at CSS was directed at managers, not the "system". The latter were condemned as "betrayers of the enterprise", thus becoming scapegoats for the failed adaption of CSS to the market-oriented reforms. Many pensioners declared to me that CSS's problems had nothing to do with "planned economy vs market economy", but were due entirely to the corruption of managers. Workers' strong resentments and even hatred toward managers meant an uneasy, even painful position for those among them who had seen themselves as mediators and allies for the workers. For instance, Laoyin, the union chairwoman, resigned from her position shortly after this clash. However, despite the militancy and fierce protests of the retirees, and despite the feelings of uneasiness and even outright sympathy among several high-level managers, the enterprise refused to cave in this time. Even though it tried to confront the pensioners with a great measure of restraint (what Laoyin referred to as "swallowing all the beating, never provoking further escalation or a fight"), the fundamental yet implicit stance was to remain steadfast. Cost-cutting (called "burden alleviation" in official discourse) had become a central state policy, and the enterprise, already on the brink of bankruptcy, saw no alternative other than to comply with this directive.

It is noteworthy that, despite sharing the same reform agenda, top managers at CSS complained that the enterprise never received support from the local government during this long confrontation. The attitude of the latter remained very hesitant and vague. From the mid-r99os, labour protests became rampant nationwide, and the issue of laid-off state workers and pensioners confronted with cuts became such a major headache for governments at various levels that whenever possible they tended to abstain from involvement and left the enterprises to address the confrontation 
themselves. ${ }^{5 \mathrm{I}}$ Even when local governments were compelled to intervene, they did so largely unwillingly and cautiously. At CSS, one day, when more than 3,000 pensioners staged a sit-down street protest in front of the CSS administration building and blocked the traffic, local policemen arrived. Cuiye, "the old revolutionary" and one of the organizers of the protest, recounts that day:

We sat there. Then the mayor came to try to persuade us to leave. We refused to listen to him. Later, he sent a fire engine in with all these policemen. I went straight to these policemen and said, "You can't disperse these people with high-pressure water. They are all old people. If one of them dies because of this, you will be in trouble. Every person should have his own conscience. Are you guys born from your parents? If we old workers sit on the street, the only thing you can do is persuasion. You can't suppress us. Suppressing the mass is illegal." Then they left. ${ }^{22}$

Other people involved also confirmed that there was actually no physical suppression during the course of this protest. Yet, the reluctance of both the enterprise and the government to take action arose no longer from a fear of breaching the socialist principles, but merely from the fear of triggering larger protests and causing further social instability. By that time, the socialist social contract had already been abandoned; the notion of "socialism", while officially still in place, had receded into official rhetoric, and the image of a "workers' state" had become increasingly obsolete, openly mocked by many as "utopia". Besides, a new generation of intellectuals identifying themselves as "liberal" had started to associate it implicitly yet meaningfully with a past marked by "excesses" and "chaos". The image of workers as "brave" and proud proletarians who create national wealth had long been replaced by one of "backward", "inefficient", and "idle" in the mass media as well as in many more intellectual publications as a way to legitimize the large-scale bankruptcy of the SOEs and the lay-off of state workers. $^{53}$

"Working class equals zero" was a widespread self-mockery among workers I interviewed. Certainly, the pensioners were well aware of this. The degradation and marginalization of the working class infuriated them

51. Among many others, see Yongshun Cai, "The Resistance of Chinese Laid-Off Workers in the Reform Period", The China Quarterly, I70 (2002), pp. 327-344; idem, State and Laid-Off Workers in Reform China: The Silence and Collective Action of the Retrenched (London, 2006); Chen, "Privatization and Its Discontents"; Lee, "Pathways of Labor Insurgency"; idem, "From the Specter of Mao"; idem, Against the Law; Beverly Silver and Lu Zhang, "China as an Emerging Epicenter of World Labor Unrest", in Ho-fung Hung (ed.), China and the Transformation of Global Capitalism (Baltimore, 2009), pp. 174-187.

52. Interview, Cuiye, 26 July 2010.

53. For this process see, for instance, Ju Li, "From 'Master' to 'Loser': Changing Working-Class Cultural Identity in Contemporary China", International Labor and Working-Class History, 88 (20I 5), pp. 190-208. 
and was one of the crucial reasons for their militancy, ${ }^{54}$ but it was also a social reality that they now had to face. The socialist social contract was gone; the close interrelation between the state and state workers was severed. This was not just because SOEs were no longer the principal economic entities, but also because the new flexible labour system and the existence of a huge reserve army of labour made workers exceedingly dispensable.

In fact, the effort to restructure SOEs during this later stage may be characterized as an attempt to break the old social contract. From the late I990s, the official mass media increasingly urged the state workers to "wean" themselves from dependence upon the state and to "jump" bravely into the "free sea of market economy" in order to "realize individual value". No matter how ridiculous buzzwords such as "independence" or "freedom" sounded to these pensioners, they finally had to realize that the old social contract - whether interpreted as "no compliance unless the regime provides its promised protection" or as "the regime will not provide protection unless workers comply" - was no longer relevant and accountable. Although they still drew upon the political discourses of class, Maoism, and socialist ideology to ground their claims - much as Ching Kwan Lee has observed in her rust-belt factory pensioners' cases ${ }^{55}$ - as time passed, these claims sounded increasingly feeble and anachronistic, no matter how militant the pensioners' fights were.

Nevertheless, pensioners' resistance persisted into 2004. The enterprise refused to compromise, and no real progress regarding the original pension subsidy was made. Pensioners and the enterprise seemed deadlocked. Then, in May of that year, as a senior manager tried to step onto a bus, an angry retiree in the queue behind him forcefully pulled him down. The senior manager fell and broke a rib, and the old man was immediately arrested, put in jail, and sentenced to two years. This incident brought a sudden halt to large-scale demonstrations, but resistance continued tenaciously. The pensioners' committees decided to change their strategies. First, they sent representatives to Beijing to appeal directly to the central state, in the hope that the central government would "care" more about their predicament than the "corrupt" local ones. They were ignored, and Beijing simply returned the case to the local government, leaving the protesters back at square one.

Then, the committee decided to turn to the law. China passed its first National Labour Law in 1994. By 1999, "ruling the country by law" was formally incorporated into Article 5 of the Constitution and has since 
become part of the official lexicon now widely adopted in government, legislature, and party reports. This more "rational" state ruled by law was meant to replace the old image of the "workers' state"; and a new social contract based on the "rule of law" was put forth and was supposed to replace the old one based on the "rule of politics". Since then, as rightly observed by Ching Kwan Lee, "legalism has become simultaneously the hegemonic ideology and the rhetoric of popular resistance". ${ }^{6}$ Having lost their old weapon drawn from the previous social contract, pensioners finally decided to take up this new weapon of law, suspiciously but hopefully. In 2004, the committee collected money from the pensioners and hired a lawyer to sue CSS. They lost the case since the court decided that the enterprise had the right to curtail its own welfare programme. Immediately afterwards, in October 2004, CSS issued a public notice through its newspaper and TV channel declaring its victory and also claiming that, from now on, the enterprise would no longer respond to any such related issues. Resistance seemed finally to be dying down. Yet, two years later, in 2006, the committee made one more effort. Again, they collected money from the pensioners and hired another lawyer, who vowed to fight for their interests. After taking the money, however, this so-called lawyer disappeared forever.

This incident served as the final blow. The largest and most militant labour protest in the history of CSS ultimately ended in a great sense of embarrassment and impotence. The failure of the last attempt to commission legal help proved fatal, not just because many participants had become exhausted by the frustrations of the long struggle, but also by the fact that they could so easily be cheated. The situation forced most of them, even the most active organizers, to realize their weakness and vulnerability in a quickly changing world that appeared increasingly incomprehensible to them. Without the reference to the socialist social contract, their formal knowledge and experiences, i.e. their "known repertoire of contention", seemed to have become irrelevant and anachronistic. This was a cruel realization for many of them. Lao Zhou, one former organizer, told me sadly: "Now I feel that I am not a social individual anymore, but only a natural individual. What is happening in this society is more and more irrelevant for me; I am now living as a biological, not a social individual." 57 It was such feelings of irrelevance and inadequacy, caused by the crumpled old "known repertoire of contention" and the crippled new one for these pensioners - as the direct result of the changing political opportunity structure - that finally defeated the movement. 


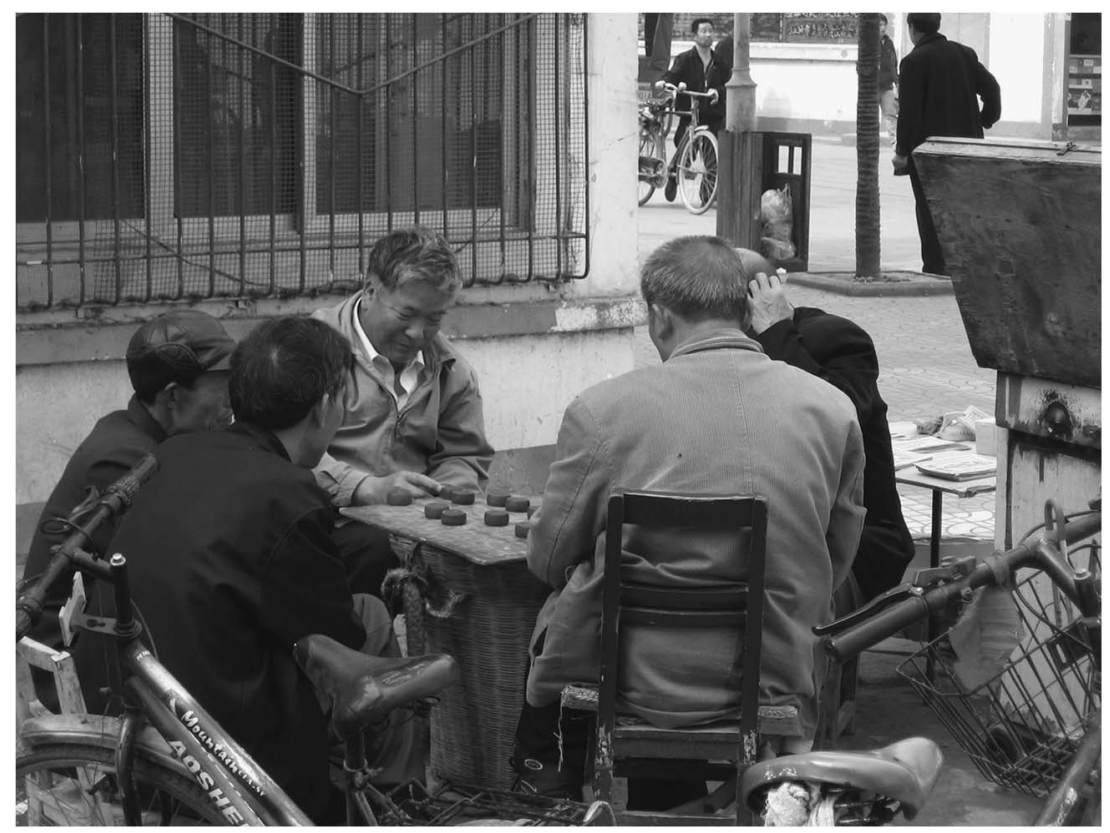

Figure I. Pensioners playing Chinese chess on a corner of the CSS residential quarters. Photo by the author. Used with permission.

Another important reason for the defeat of the pensioners' mobilization at CSS is the fact that they remained isolated. As in the I980s, none of the workers employed at that moment ever got involved in these mobilizations, for various reasons. As such, the pensioners' "segregated" protests remained insufficient to generate a sense of threat to what was most important to both the enterprise and the different levels of government: social stability. Consequently, they could ultimately be disregarded - a fact that was merely affirmed by the outcome of the legal proceedings.

\section{FROM STRENGTH TO FRAILTY - THE CONTENTIOUS ACTION OF A GENERATION IN A SHIFTING CONTEXT}

The pioneering generation of workers at Chinese SOEs starting to work in the 1950s/I960s experienced several different general political and economic contexts for their lives, their experience as workers, and their contentious collective action. It has come a long way, from yielding surprising power in defending its interests to becoming a relatively marginalized group who not only had to accept defeat, but also symbolic degradation. By analysing and comparing three waves of contentious 
collective action employed by this pioneering generation of Chinese state workers at one particular SOE from the I960s to the present, I have argued that the changing political opportunity structure in different historical periods has greatly conditioned workers' "repertoires of contention" at each moment and, hence, significantly affected the processes, strategies, and outcomes of workers' contentious collective action.

The experiences of these workers (later pensioners) highlight the importance of systematically contextualizing workers' contentious politics in different historical periods in order to draw attention to not only how the changing political opportunity structure motivated, provoked, or suppressed workers' contentious politics, but also how it affected the outcome of these actions. Both the radical political environment during the Cultural Revolution as well as the development of a paternalistic and hegemonic factory regime conditioned by the socialist "cage" during early-stage reform in the I980s offered the pioneering generation of workers at CSS certain opportunities to employ their "known repertoire of contention" in order to exert pressure through both organized and spontaneous contentious collective action. Most of the time they succeeded, albeit to a limited extent and over a limited time span. More comprehensive market reform since the mid-I990s, however, resulted in the loosening of political constraints and the abandonment of the previous socialist social contract. This provoked the largest and most militant and desperate movement organized by these workers, now pensioners. Nonetheless, the outdated ness of the old "repertoire of contention" under this new political opportunity structure led to their final defeat.

As this article has argued, it is necessary to revise the notion of the "socialist social contract" in order to allow one to understand the paradoxical and changing role it played in workers' contentious collective action. The socialist social contract could serve as a crucial component of the "repertoire of contention" for workers when a particular political opportunity structure opened the possibility of workers interpreting it as "the regime has to provide secure job tenure and fair welfare services as promised by the socialist ideology". Under such circumstances, the socialist social contract empowered rather than disempowered workers, particularly during the Cultural Revolution and the early-stage reforms of the i980s. Conversely, when the political opportunity structure tightened and no longer encouraged or tolerated this interpretation, workers would be impelled to interpret the contract as "unless workers comply, the regime would not offer provisions" and would become, at least outwardly, more acquiescent. Under these circumstances, the socialist social contract discouraged contentious politics and effectively "bought out" workers. By the time the old socialist contract was abandoned completely during the later-stage reform of the I990s, workers who still referred to the contract as a crucial component of their "known repertoire of contention" were likely 
to fail. Meanwhile, the new social contract put forth by the regime - one based ostensibly on "the rule of law" - not only did not work out for the contentious pensioners, it resulted in a defeat that conveyed a strong sense of embarrassment and inadequacy. The weapons to be forged based on this new social contract felt alien and obscure to a group of workers who had learnt the main lessons of their "repertoire of contention" under completely different circumstances. For this generation, then, the final episode of contention was more than a defeat in a specific struggle; it appeared to be the silent vanishing of a certain kind of collective experience. This world, hence, ended "not with a bang but a whimper". ${ }^{8}$

\section{TRANSLATED ABSTRACTS \\ FRENCH - GERMAN - SPANISH}

Ju Li. Victoire et défaite. La politique contestataire d'une génération d'ouvriers d'État en Chine depuis les années I960.

En analysant et comparant trois vagues d'action collective contestataire d' une génération pionnière d'ouvriers d'État en Chine dans une entreprise d'État déterminée des années 1960 à nos jours, cet article tente d'expliquer les formes variables de cette action et d'analyser son efficacité à différentes périodes historiques. Je soutiens que la structure changeante des opportunités politiques dans divers contextes historiques a largement conditionné le "répertoire de la contestation" à chaque moment et a donc considérablement affecté les processus, les stratégies et les résultats de l'action collective contestataire des ouvriers. Dans cet article, je souligne le rôle paradoxal du contrat social socialiste en tant que composant potentiel mais crucial du "répertoire de la contestation", en faisant valoir que différentes interprétations du contrat, conditionnées par une structure déterminée des opportunités politiques à différentes périodes historiques, purent favoriser ou non l'appropriation du pouvoir d'agir des ouvriers travailleurs. La recherche historique d'archives et la recherche historique orale sont toutes deux utilisées dans cette étude.

Traduction: Christine Plard

Ju Li. Triumph und Niederlage. Die kämpferische Politik einer Generation staatsbetrieblich beschäftigter Arbeiter in China seit den I960er Jabren.

In diesem Aufsatz werden drei Wellen (von den 1960er Jahren bis zur Gegenwart) des kämpferischen kollektiven Handelns einer Pioniergeneration chinesischer Arbeiter in einem bestimmten Staatsbetrieb untersucht. Damit sollen die unterschiedlichen Formen erklärt werden, die dieses kollektive Handeln angenommen hat, und es soll dessen Wirksamkeit in verschiedenen historischen Phasen analysiert

58. T.S. Eliot, “The Hollow Men”, in The Complete Poems and Plays: 1909-1950 (Orlando, 197I), pp. 56-59. 
werden. Im Aufsatz wird die These vertreten, der sich von einem historischen Kontext zum anderen verändernde Möglichkeitsrahmen habe das "Kampfrepertoire” der Arbeiter zu jedem Zeitpunkt stark geprägt und einen wesentlichen Einfluss auf die Prozesse, Strategien und Ergebnisse ihres kämpferischen Handelns ausgeübt. Außerdem wird im Aufsatz die paradoxe Rolle betont, die der sozialistische Gesellschaftsvertrag als potenzieller aber auch ausschlaggebender Bestandteil des "Kampfrepertoires” gespielt hat: Verschiedene, von dem in unterschiedlichen historischen Phasen jeweils gegebenen Möglichkeitsrahmen geprägte Auslegungen dieses Gesellschaftsvertrags konnten die Arbeiter entweder ermächtigen oder schwächen. In der Untersuchung wird sowohl von Archivmaterialien als auch von Befunden der oral history Gebrauch gemacht.

Übersetzung: Max Henninger

Ju Li. Victoria y derrota. La política contenciosa de una generación de trabajadores del Estado en China desde la década de 1960.

A través del análisis y comparación de las tres oleadas de acción colectiva contenciosa desarrollada por la generación pionera de trabajadores de una particular empresa estatal en China, desde la década de i 960 hasta la actualidad, este artículo tiene por objeto el explicar sus formas diferentes y trata de analizar su eficacia en diferentes periodos históricos. Planteo que la cambiante estructura de las oportunidades políticas en diversos contextos históricos ha condicionado de forma intensa el "repertorio de la contención" de los trabajadores en cada momento y, por consiguiente, ha afectado de forma significativa a los procesos, estrategias y logros de la acción colectiva contenciosa de los trabajadores. En el texto se subraya el rol paradójico de contrato social socialista como un compenente potencial (y crucial), del "repertorio de la contención”, con el argumento de que diferentes interpretaciones del contrato como algo condicionado por una cierta estructura de oportunidades políticas en diferentes periodos de la historia podía podían tanto empoderar como desempoderar a los trabajadores. Para elaborar este análisis se han empleado tanto fondos de archivo como la investigación en historia oral. 